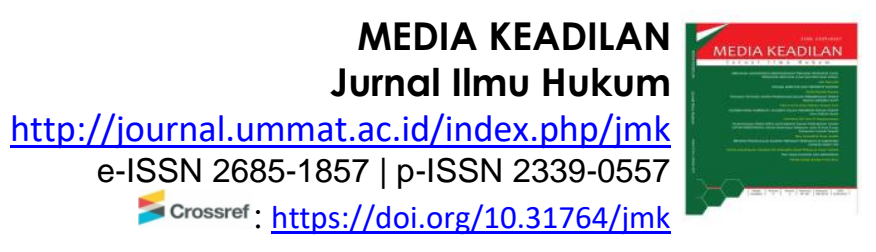

\title{
PILKADA SERENTAK DARI PERSPEKTIF KONFLIK
}

\author{
Fanila Kasmita Kusuma1 \\ Dosen Institut Pemerintahan Dalam Negeri Kampus Nusa Tenggara Barat \\ Email1:fanilakasmitakusuma@gmail.com \\ DOI:https://doi.org/10.31764/jmk.v9i2.888
}

Received: July 30, 2018, Accepted: Augt 30, 2018 /Published: Okt 30, 2018

\begin{abstract}
This article discusses simultaneous local elections from a conflict perspective. The process of democracy (electoral), conflict is a necessity because every individual or social group has different interests, understandings, and values. Conflict is relatively easy to come from more complex social bases. Democracy is also believed to be a means of transforming conflict. The research method used is normative legal research, with a statute approach and conceptual approach. Analyzed descriptively qualitatively. As for the results of research, that democracy seeks to transform conflict in the form of violence toward the voting booths, from coercive to persuasive. However, democracy and conflict are actually two things that are not easily connected. From many experiences, it is not easy to prove that democracy can be a trigger for conflict, although it can be claimed that the escalation of conflict is caused by political liberalization at work in the democratic process. The existence of a natural conflict for a democratic process. It becomes dangerous if the conflict is repressive and takes the form of violence.

Keywords: conflict; simultaneous local election.
\end{abstract}

\begin{abstract}
ABSTRAK
Artikel ini membahas tentang pilkada serentak dari perspektif konflik. Proses demokrasi (elektoral), konflik merupakan sebuah keniscayaan karena setiap individu atau kelompok sosial memiliki kepentingan, pemahaman, dan nilai yang berbeda-beda. Konflik relatif mudah hadir dari basis sosial yang lebih kompleks. Demokrasi juga diyakini sebagai sarana untuk mentransformasikan konflik. Metode penelitian yang digunakan adalah penelitian hukum normatif, dengan statute approach dan conceptual approach. Dianalisis secara deskriptif kualitatif. Adapun hasil penelitian, bahwa demokrasi berupaya mentransformasikan konflik yang berwujud kekerasan ke arah bilik suara, dari memaksa (coercive) ke persuasif. Meski demikian, demokrasi dan konflik sebenarnya juga merupakan dua hal yang tidak mudah dihubungkan. Dari banyak pengalaman yang ada, bukan hal yang mudah membuktikan bahwa demokrasi dapat menjadi pemicu konflik, walaupun dapat diklaim bahwa eskalasi konflik disebabkan oleh liberalisasi politik bekerja dalam proses demokrasi. Eksistensi konflik wajar bagi suatu proses demokrasi. Menjadi berbahaya jika konflik sudah represif dan berwujud kekerasan (violence).
\end{abstract}

\section{5 | Media Keadilan: Jurnal Ilmu Hukum |}




\section{Kata kunci: konflik; pilkada serentak.}

\section{PENDAHULUAN}

Konflik berasal dari kata kerja Latin configure yang berarti saling memukul. Secara sosiologis, konflik diartikan sebagai suatu proses sosial antara dua orang atau lebih (bisa juga kelompok) dimana salah satu pihak berusaha menyingkirkan pihak lain dengan menghancurkannya atau membuatnya tidak berdaya. ${ }^{1}$

Demokrasi berupaya mentransformasikan konflik yang berwujud kekerasan ke arah bilik suara, dari memaksa (coercive) ke persuasif. ${ }^{2}$ Meski demikian, demokrasi dan konflik sebenarnya juga merupakan dua hal yang tidak mudah dihubungkan. Dari banyak pengalaman yang ada, bukan hal yang mudah membuktikan bahwa demokrasi dapat menjadi pemicu konflik, walaupun dapat saja diklaim bahwa eskalasi konflik disebabkan oleh liberalisasi politik yang bekerja dalam proses demokrasi. Jadi eksistensi konflik memang suatu hal yang wajar bagi suatu proses demokrasi. Hanya saja, menjadi berbahaya jika konflik sudah represif dan berwujud kekerasan (violence). Pilkada berupaya mengarahkan agar konflik tidak meluas menjadi kekerasan. Sayangnya, idealitas yang dibangun dalam sebuah proses demokrasi, pada kenyataannya seringkali jauh dari apa yang diharapkan. ${ }^{3}$

Pilkada yang dirancang sebagai demokrasi elektoral, justru menjadi ajang baru timbulnya konflik kekerasan dan benturan-benturan fisik antar pendukung calon kepala daerah menjadi pemandangan jamak yang ditemui. Singkatnya, mekanisme demokrasi yang ada seolah justru melegitimasi munculnya kekerasan akibat perbedaan yang sulit ditolerir

\footnotetext{
1 Budiardjo, Miriam, Dasar-Dasar Ilmu Politik, Gramedia Pustaka Utama, Jakarta. 2003, Hal 12.

2 Bratakusumah, Deddy Supriady dan Dadang Solihin, Otonomi Penyelenggaraan Pemerintahan Daerah, PT Gramedia Pustaka Utama, Jakarta. 2002, Hal 45.

${ }^{3}$ Gadjong, Agussalim Andi, Pemda (Kajian Politik Dan Hukum), PT. Ghalia Indonesia, Jakarta. 2007, Hal 63.
} 
antara pihak-pihak berkepentingan di arena demokrasi. Dengan kata lain, desain demokrasi di Indonesia dalam konteks penyelenggaraan pilkada telah gagal sebagai cara mentransformasikan konflik.

Kegagalan tersebut disebabkan oleh beberapa hal. Pertama, pemilu yang diperkenalkan di Indonesia selama ini dibangun atas basis pondasi preferensi individu. Diumpamakan bahwa mereka yang berinteraksi adalah individu- individu otonom yang masing-masing memiliki preferensi tersendiri, one man, one vote, one voice. ${ }^{4}$ Asumsi ini sangat problematik jika dihadapkan pada masyarakat Indonesia, yang sebagai individu tidak pernah lepas dari kategorisasi-kategorisasi sosial yang membentuknya. Sebagaimana di Papua, satu suara lahir dari suatu honai (keluarga/rumah tangga), bukan dari satu individu. Dari pilihan basis sosialnya, individu baru kemudian akan mempertimbangkan pilihan-pilihannya terhadap kandidat yang tampil dalam pemilu. Kandidat dalam hal ini juga tidak sekedar sebagai kandidat pilkada tetapi juga tokoh yang dianggap mewakili basis sosial tertentu. Tidak mengherankan jika kemudian tokoh masyarakat seperti Kyai, Tuan Guru, Ustadz, kepala suku atau tokoh panutan lain, akan lebih menentukan preferensi-prefensi atau pilihan individu untuk bertindak secara politik. Kedua, jika melihat logika cara mengelola elektoralisme di Indonesia, maka yang berlaku adalah logika "winner take all", "kalau saya dapat, yang lain tidak akan dapat". Dengan kata lain, logika yang terbentuk adalah demokrasi dengan desain mediteranisme yang pada prinsipnya "siapa yang menang, maka dia yang akan mendapatkan segalanya", sementara bagi yang kalah harus menunggu lima tahun lagi. ${ }^{5}$

\footnotetext{
4 Bachrul, Elmi, Keuangan Pemerintah Daerah Otonom di Indonesia, Universitas Indonesia Press, Jakarta. 2002, Hal 23.

5 Arbas, Cakra, Jalan Terjal Calon Independen pada Pemilukada di Provinsi Aceh, PT. Sofmedia, Jakarta. 2012, Hal 56.
} 
Logika winner take all menciptakan dominasi kekuasaan, sebab konsekuensi dari kemenangan kepala daerah dari komunitas tertentu akan menciptakan "gerbong" birokrasi atas dasar basis sosial di lingkup pemerintahan daerah. Posisi-posisi birokrasi strategis akan dipegang oleh orang-orang yang berasal dari basis sosial yang sama. Sebaliknya, orangorang (pejabat) yang berasal dari basis sosial berbeda akan tersingkir pada posisi pinggiran, yang bahkan sama sekali tidak diperhitungkan.

Pilkada yang bekerja dengan logika socially bounded individu dan winner take all memunculkan persoalan konflik yang cukup rumit. Kompleksitas salah satunya berakar pada karakter masyarakat Indonesia sendiri. Struktur sosial yang terfragmentasi dimana masing-masing kelompok memiliki basis kuat, nampak tidak kompatibel dengan logika Pilkada yang dibangun pemerintah. Dilihat dari struktur masyarakat plural seperti itu, Pilkada tidak bisa lagi dilihat hanya sekedar persoalan rekruitmen kepala daerah, tetapi lebih kompleks dari itu, Pilkada menyangkut persoalan "hidup mati" sebuah komunitas.

Pada sisi yang lain, mekanisme demokrasi sebagaimana sebelumnya dipaparkan cenderung menjadikan masyarakat bersikap "pra bayar". Masyarakat bukannya lebih memilih menggunakan momentum pilkada untuk menyalurkan aspirasi dan kepentingannya secara ideologis, mereka justru menjadikan pilkada sebagai bagian dari sumber pendapatan uang tunai. Daripada mengaharap janji-janji Pemilu yang sudah sering tidak ditepati, masyarakat lebih memilih memperoleh uang tunai di awal sebelum menentukan pilihan. Mereka nampak telah skeptis dan berpikir bahwa akan lebih sulit mendapatkan kompensasi apapun dari pemenang pilkada setelah hingar bingar berlalu. Masyarakat seakan tahu: lebih baik memilih mengambil keuntungan di awal karena mereka tahu setelah pilkada, mereka akan ditinggalkan. Jika demikian, maka persoalan konflik pilkada bukan semata-mata karena adanya provokator atau adanya 
mekanisme dan regulasi yang tidak tepat. Tetapi konflik lahir sebagai dampak logika pilkada yang bersandar pada basis sosial amat kuat.

\section{METODOLOGI}

Penelitan ini digunakan penelitian hukum normatif, yaitu penelitian yang dilakukan terhadap asas-asas hukum, kaedah-kaedah hukum dalam arti nilai (norm), peraturan hukum konkrit dan sistem hukum, ${ }^{6}$ yang berhubungan dengan materi yang diteliti. Pendekatan masalah yang digunakan yaitu pendekatan perundang-undangan (statute approach), dan pendekatan konseptual (conceptual approach). Menggunakan bahan hukum primer, sekunder, dan tersier, kemudian dianalisis secara deskriptif kualitatif.

\section{PEMBAHASAN}

\section{A. Terjadinya Konflik Pilkada dan Penyebabnya}

Terlepas dari suksesnya pilkada di Jakarta, banyak konflik yang pernah terjadi saat maupun pasca pilkada khususnya konflik horizontal antar masyarakat pendukung pasangan calon. Internasional Crisis Group (ICG) mencatat sekitar 10 persen dari 200 pemilihan umum Kepala Daerah dan Wakil Kepala Daerah yang digelar sepanjang tahun 2017 diwarnai aksi kekerasan. Seperti di Mojokerto, Jawa Timur, Tana Toraja di Sulawesi Selatan dan Toli-toli di Sulawesi Tengah. ICG menyebutkan bahwa kekerasan dalam Pilkada antara lain dipicu oleh lemahnya posisi penyelenggara Pemilu, seperti Komisi Pemilihan Umum kabupaten/kota dan Panitia Pengawas Pemilu (Panwaslu) Jika dianatomi, beberapa sumber konflik horizontal yang berujung pada tindak kekerasan dalam

\footnotetext{
${ }^{6}$ Sudikno Mertokusumo, Penemuan Hukum, Liberty, Yogyakarta, 2004, Hlm. 29.
} 
Pilkada disebabkan beberapa hal diantaranya $:^{7}$

a. Adanya rasa ketidakpuasan dari pasangan calon atau pendukung pasangan calon ketika gugur dalam tahap pencalonan

Kejadian ini terjadi pada Pilkada Kabupaten Mojokerto Tahun 2010. Selain Mojokerto, kekerasan yang dilakukan pendukung pasangan calon akibat gugur dalam tahap pencalonan juga terjadi dalam pilkada di Kabupaten Puncak Provinsi Papua yang menewaskan sekitar 19 orang. Konflik terjadi akibat KPU setempat menolak salah satu pasangan calon yang diajukan oleh Partai Gerindra karena partai tersebut sebelumnya sudah mendaftarkan pasangan calon yang lain. Akibatnya terjadi dualisme dukungan yang diberikan oleh Partai Gerindra kepada dua pasangan calon yang berbeda.

b. Adanya rasa tidak puas pasangan calon terhadap hasil penghitungan Pilkada.

c. Tahapan pendaftaran pemilih yang amburadul inilah yang mengakibatkan konflik pada pemungutan dan penghitungan suara.

Diakui bahwa sengketa Pilkada memang banyak diawali oleh tidak maksimalnya proses pendaftaran pemilih. Pengalaman Pilkada selama ini menunjukan bahwa ketika pemutahiran data pemilih tidak maksimal dan mengakibatkan banyaknya warga yang tidak terdaftar sebagai pemilih tetap, maka kemungkinan besar terjadi protes dan konflik ketika hari-H. Karena pendataan pemilih yang kurang valid, pada saat penetapan pemenang biasanya akan terjadi kekisruhan. Fenomena yang sering muncul adalah pihak yang kalah apalagi mengalami kekalahan dengan angka tipis selalu mengangkat isu penggelembungan suara, banyak warga yang tidak terdaftar dan persoalan pendataan pemilih lainnya sebagai sumber utama kekalahan. Massa yang merasa tidak mendapatkan hak pilihnya biasanya memprotes dan dimanfaatkan oleh pasangan yang kalah.

Kejadian ini pernah terjadi dalam Pilkada di Sumatera Selatan, dimana pendukung Syahrial Oesman menuding adanya

7 Kaloh, J., Kepala Daerah-Pola Kegiatan, Kekuasan, dan Perilaku Kepala Daerah, dalam Pelaksanaan Otonomi Daerah, Gramedia, Jakarta.2003, Hal 12 
penggelembungan suara di Kabupaten Musi Banyuasin yang mengakibatkan kemenangan tipis Alex Noerdin. Selain itu kisruh pilkada juga terjadi di Tana Toraja Sulawesi Selatan Tahun 2010. Kerusuhan dipicu ketidakpuasan ratusan pendukung dua pasangan calon bupati dan Wakil bupati, yakni Nikodemus Biringkanae-Kendek Rante dan pasangan Victor Datuan Bata-Rosina Palloan, atas hasil penghitungan sementara pemilihan umum kepala daerah yang dilakukan beberapa lembaga survei. Kerusuhan itu menyebabkan 1 orang tewas dan 10 orang luka berat dan ringan. Kerusuhan juga mengakibatkan sejumlah bangunan kantor pemerintahan rusak, seperti Kantor Komisi Pemilihan Umum (KPU) Tana Toraja, Kantor Panitia Pengawas Pemilihan Umum (Panwaslu), Gedung DPRD, Kantor Dewan Pimpinan Daerah Partai Golongan Karya, dan rumah dinas Bupati Tana Toraja Johannes Amping Situru. Ketidakpuasan warga terhadap hasil Pilkada juga terjadi di Kabupaten Soppeng dan Kabupaten Maros, Sulawesi Selatan. Di Soppeng, massa merusak Kantor KPU Soppeng dan dua kantor kecamatan, yakni Takkalala dan Lalabata. Sementara di Maros, massa melempari Kantor Kecamatan Tabralili dengan bom Molotov. Kerusuhan akibat rasa tidak puas terhadap hasil Pilkada juga pernah terjadi pada tahun 2006 di Kabupaten Tuban Jawa Timur. Kerusuhan itu mengakibatkan beberapa bangunan umum seperti Pendopo Kabupaten Tuban hangus dibakar massa.

Selain itu, Pemicu lain yang biasanya memunculkan konflik dalam Pilkada adalah tidak bersedianya DPRD menetapkan hasil Pilkada. Meskipun tidak memiliki dampak yuridis terhadap hasil Pilkada, namun penolakan DPRD tersebut memunculkan sengketa politik berkepanjangan pasca Pilkada. Seperti misalnya yang terjadi pada Pilkada Banyuwangi 2005 di mana pihak DPRD bersikukuh menolak penetapan Bupati Banyuwangi terpilih. Kasus penolakan penetapan oleh DPRD biasanya diawali oleh kekalahan pasangan calon yang didukung oleh banyak partai 
yang secara politik memiliki kekuatan signifikan di DPRD. Dan umumnya penolakan tersebut berujung pada tidak harmonisnya hubungan kekuatan eksekutif dan legislatif pasca Pilkada.

\section{B. Cara Meminimalisasi dan Mengatasi Konflik Pilkada}

Pilkada langsung merupakan salah satu kemajuan terbesar dalam reformasi politik di Indonesia. Pilkada merupakan ikhtiar rakyat Indonesia terhadap demokrasi langsung. Namun di balik eforia pilkada langsung dewasa ini, ada masalah lain yang dapat membuat agenda politik lokal ini paradoks, yakni potensi konflik yang dikandungnya. Hal ini telah diingatkan banyak kalangan sejak awal. Potensi konflik jelas menjadi salah satu pekerjaan rumah seluruh perencana dan penyelenggara Pilkada langsung. Kalau tidak diantisipasi baik sejak dini, pilkada- pilkada selanjutnya bakal menimbulkan konflik politik yang lebih besar lagi dibanding contoh konflik diatas yang tidak hanya merugikan kepentingan rakyat, tetapi juga merusak benih-benih demokrasi serta mengganggu proses penguatan demokrasi di tingkat lokal maupun nasional. ${ }^{8}$

Ilmuwan politik Juan J Linz dan Alfred Stepan mengatakan, ${ }^{9}$ suatu negara dikatakan demokratis bila memenuhi prasyarat antara lain memiliki kebebasan kepada masyarakat untuk merumuskan preferensipreferensi politik mereka melalui jalur-jalur perserikatan, informasi dan komunikasi; memberikan ruang berkompetisi yang sehat dan melalui cara-cara damai; serta tidak melarang siapapun berkompetisi untuk jabatan politik. Dalam hal ini jelas, kompetisi politik yang damai menjadi prasyarat penting bagi demokrasi.

Salah satu agenda terpenting dalam konteks Pilkada langsung

\footnotetext{
8 Ibid, hal 20

9 Kaloh, J., Dalam Juan J Linz, Dkk, Kepala Daerah-Pola Kegiatan, Kekuasan, dan Perilaku Kepala Daerah, dalam Pelaksanaan Otonomi Daerah, Gramedia, Jakarta.2003, hal. 17
} 
adalah meminimalisasi potensi-potensi konflik tersebut, antara lain dengan:

\section{a. Conflict Governance}

Conflict governance idealnya adalah mekanisme politik yang mentransformasikan konflik yang tidak produktif atau konflik kekerasan menjadi konflik yang produktif, konflik produktif mengartikan dirinya sebagai praktik negosiasi terus menerus dalam ruang politik yang mendasarkan pada prinsip- prinsip demokrasi. Demokrasi deliberatif dalam hal ini adalah fondasi yang paling tepat bagi conflict gevernance. Nogosiasi yang berdiri di atas akal sehat, imparsialisme, mendengarkan, kesetaraan, nir-kekerasan, dan aturan main legal.

Contoh sengketa pilkada yang dapat diselesaikan dengan conflict governance ialah kisruh pilkada di Jawa Timur dimana MK atau Mahkamah Konstitusi sebagai lembaga demokrasi bisa menjalankan fungsinya sebagai containment of violence. Mahkamah Konstitusi pada saat itu memerintahkan pencoblosan ulang di kabupaten Bangkalan dan Sampang, serta penghitungan suara di Pamekasan.

Selain itu MK juga memerintahkan KPU dan Bawaslu untuk benarbenar mengawasi pemilihan ulang dan penghitungan suara ulang di tiga kabupaten terebut agar tercipta pemilu yang jujur dan adil. MK menilai, secara materil telah terjadi pelanggaran ketentuan pilkada yang berpengaruh terhadap perolehan suara. Kubu Karsa dan Kaji menerima keputusan tersebut secara terbuka dan optimis. Dari hasil coblosan dan penghitungan ulang, serta ditambahkan dengan suara di 36 kabupaten lainnya, Karsa tetap memenangi pilgub Jatim. Dengan hasil ini kubu Khofifah tetap tidak puas dan mengajukan gugatan kembali ke Mahkamah Konstitusi, namun Mahkamah Konstitusi menolak gugatan dari Kubu Kaji karena menggangap kesalahan bukan 
berasal dari kubu lawan melainkan dari pihak penyelenggara.

Pelembagaan democratic conflict governance menyediakan tiga mekanime. Yaitu mekanisme pengamanan, resolusi konflik, dan rekonsiliasi di setiap tingkat kepemimpinan grass root. Setiap mekanisme dilaksanakan oleh lembaga-lembaga kompeten yang telah ada dalam struktur pemerintahan dan lembaga yang dibentuk secara ad hoc oleh berbagai kelompok kepentingan terlibat. Seperti pada mekanisme pengamanan, aparat keamanan dalam hal ini lembaga kepolisian menjadi penanggung jawab utama. Untuk menjalankan mekanisme conflict governance, lembaga kepolisian perlu memiliki kualitas dalam mobilitas aparat keamanan ke pusatpusat dinamika konflik massa. Kepolisian harus juga memiliki kemampuan menilai dinamika konflik dalam masyarakat. Sehingga, penanganan dini bisa segera diciptakan untuk mencegah terjadinya eskalasi kekerasan.

Hal yang tidak kalah penting adalah kapasitas persuasi terhadap massa yang telah membakar emosi dan siap menciptakan kekerasan. Mekanisme resolusi konflik memiliki dua dimensi. Yaitu dimensi judicial settlement dan negosiasi untuk win-win solution. Mekanisme ini difasilitasi oleh lembaga-lembaga demokrasi formal seperti KPU dan Lembaga Peradilan. Walupun demikian mekanisme ini hanya bisa berjalan tatkala elit politik memiliki komitmen terhadap demokrasi.

Hal menarik terhadap kasus sengketa pilkada Jatim, para cagub dan cawagub merupakan figur-figur yang selama ini berperan dalam demokratisasi di Indonesia. Terutama sekali Khofifah Indar Parawansa dari Kaji dan Syaifullah Yusuf dari Karsa. Sehingga mekanisme resolusi konflik ini bisa bekerja karena ada kepemimpinan demokratis yang menyadari pentingnya memanfaatkan mesin demokrasi.

Mekanisme rekonsiliasi di setiap level kepemimpinan grass root merupakan proses sosial yang mendorong kerukunan lintas kelompok 
identitas massa pendukung. Idealnya mekanisme ini dijalankan oleh lembaga lintas kelompok, partai politik dan lembaga formal pemerintah seperti kepolisian dan KPU. Sayangnya mekanisme ketiga dari democratic conflict governance belum diadopsi dalam sengketa pilkada Jatim. Padahal aksi kekerasan massa grass root seringkali terlepas dari kemampuan kontrol para elite politiknya. Kesadaran massa akar bawah lebih banyak dipengaruhi oleh fanatisme kelompok daripada seruan politik. Sehingga politik dengan kesadaran demokrasi belum tentu menjamin bahwa kekerasan massa akar ruput bisa dicegah.

Harapan kemenangan di tingkat massa grass root terhadap para figur elite politik seringkali merupakan refleksi kepentingan identitas kelompok. Kemenangan figur tertentu dianggap kemenangan kelompok identitas tertentu. Sehingga pada dasarnya massa grass root memiliki suatu proses tersendiri dalam memaknai sengketa pilkada yang tidak selalu bisa dikontrol oleh elite politiknya. Sehingga fakta sosiologis ini sangat sulit hanya ditangani oleh meknisme pengamanan dan resolusi konflik. Sebenarnya mekanisme rekonsiliasi di setiap tingkat kepemimpinan grass root. Sehingga kemungkinan kekerasan tetap menjadi tantangan bagi demokrasi lokal di Jatim khususnya dan bagi demokrasi Indonesia umumnya. Sengketa pilkada Jatim sebenarnya bisa dijadikan sebagai peletakan batu pertama model conflict governance dalam pilkada di Indonesia. Sehingga resiko demokrasi dalam bentuk pembiayaan tinggi tidak semakin diperparah oleh hadirnya kekerasan politik.

\section{b. Kesadaran Demokrasi}

Fondasi dari conflict governance dalam konteks pilkada damai adalah kesadaran demokrasi. Artinya mekanisme-mekanisme dalam 
democratic conflict governance hanya akan berjalan efektif dan menjadi mesin perdamaian tatkala seluruh masyarakat memiliki kesadaran demokratis. Yaitu suatu kesadaran yang dibentuk oleh nilai-nilai kemanusiaan dan kepercayaan hukum. Baik di tingkat politik dan massa grass root kesadaran non demokratis masih mewarnai di setiap dimensi tindakan politik. Termasuk tindakan politik dalam pilkada. Salah satu kasus menonjol di tahun ini dari kesadaran nondemokratis muncul dalam sengketa pilkda di Maluku Utara. Sehingga kekerasan politik pun tidak bisa dihindarkan. Sengketa pilkada di Sumatera Selatan juga masih melahirkan tindakan kekerasan politik di tingkat massa grass root. Menjadikan democratic conflict governance sengketa pilkada Jatim sebagai model kelola konflik damai harus dimulai terlebih dahulu dari kesadaran demokrasi. Tanpa kesadaran demokrasi, mekanisme conflict governance hanya akan muncul secara prosedural. Kekerasanpun bisa saja tetap pecah kepermukaan.

\section{c. Undang-Undang}

Untuk mengatasi dan meminimalisasi konflik pilkada diperlukan suatu Undang-Undang tersendiri tentang tata kelola konflik publik termasuk konflik pemilu. Negara melalui organisasiorganisasinya harus mampu mereduksi kekerasan partai politik dan menciptakan konflik kepentingan yang konstruktif untuk pembangunan perdamaian.

\section{d. Melaksanakan Good Government}

Dengan adanya Good Government, secara perlahan ajang pilkada tidak akan diperebutkan sebagai serana mendapatkan keuntungan materi dan politik semata, namun sebagai sarana melayani publik serta mensejahterkan rakyat sehingga potensi konflik pemilu yang terjadi baik itu karena kekalahan dalam hasil pemungutan suara dan 
lain sebagainya dapat diminalisir.

e. Mempertimbangkan faktor penguatan masyarakat sipil dan modal sosial berupa kepercayaan antara warga dan elemen-elemen masyarakat.

Pada konteks ini, tersedianya modal sosial kultural berupa kepercayaan dari setiap warga dan terbukanya ruang dialog akan berguna untuk mentransformasikan konflik politik. Ketika persoalan muncul, peritmbangan rasional dan jernih berbasis social trust akan mereduksi cara-cara kekerasan. Social trust antara warga dan keterbukaan ruang publik akan membuat warga semakin peka terhadap lingkungan sosial maupun provokasi dari luar atau elite yang mengguncang. Konflik memang tidak bisa dihindari di wilayah demokrasi yang masyarakatnya multikultural, terlebih kalau elite politiknya tidak memiliki kedewasaan dalam berdemokrasi. Tetapi paling tidak menurut Cohen dalam manajemen konflik, bagaimana kita bisa secara cerdas meminimalisir konflik itu sendiri. Dalam konteks pilkada, setiap kandidat harus memiliki modal dasar demokrasi yaitu "Sportifitas" mengakui keunggulan orang lain dan menerima kekalahannya dengan lapang dada tanpa mencari kambing hitam.

Tujuan utama penyelenggara pemilu adalah mengantar pemilu yang bebas dan adil kepada para pemilih. Untuk itu, KPU harus melakukan semua fungsinya dengan dengan tidak berpihak dan secara efektif harus menyakinkan bahwa integritas setiap proses atau tahapan pemilu terlindungi dari oknum-oknum yang tidak kompeten dan yang ingin bertindak curang. Kegagalan memenuhi tugas yang paling sederhana pun tidak hanya mempengaruhi kualitas pelayanan, tapi juga akan menimbulkan persepsi publik tentang kompetensi dan ketidakberpihakan dari aministrator pemilu.

Penyelenggaraan pemilu yang bebas, adil, dan ideal untuk 
melaksanakan pemilu harus memperhatikan hal berikut:

1) Adanya kemandirian dan ketidakberpihakan

KPU tidak boleh menjadi alat yang dikendalikan oleh seseorang, penguasa atau partai politik tertentu. KPU harus berfungsi tanpa bias atau kecenderungan politis.

2) Efisiensi

Efisiensi adalah bagian yang tidak dapat dipisahkan dari keseluruhan kredibilitas proses pemilu. Pada saat dihadapkan dengan dugaan-dugaan dan contoh-contoh ketidakmampuan, sulit bagi lembaga pemilu untuk mempertahankan kredibilitasnya.

3) Profesionalisme

Pemilihan umum juga memiliki arti penting dalam fungsi demokrasi dimana anggota KPU harus memiliki pengetahuan yang mendalam mengenai prosedur pemilihan umum dan filosofi pemilihan umum yang bebas dan adil, diberi wewenang untuk melaksanakan dan mengatur proses tersebut.

4) Kompeten, tidak berpihak dan penanganan yang cepat terhadap pertikaian yang ada.

Ketetapan undang-undang harus dijabarkan pada hal yang sangat operasional sehingga setiap anggota KPU dapat mengatasi setiap permasalahan yang muncul dalam memproses dan menengahi keluhan atas pelaksanaan pemilu, seperti dugaan kecurangan ataupun konflik antar kelompok atau dalam regulasi yang bersifat memaksa sekalipun. Partai-partai politik, dan masyarakat pada umumnya berkeinginan agar keluhan mereka didengar dan ditindak lanjuti dengan cepat dan efisien oleh KPU atau lembaga terkait. Kredibilitas administrasi KPU, pada banyak kesempatan, tergantung pada kemampuan untuk mengurusi hal-hal yang berkaitan dengan keluhan-keluhan dalam pemilu. Berhadapan dengan kekhawatiran dan kecurigaan yang biasanya hadir pada masa transisi, KPU harus memiliki sumber daya dan kompeten memahami aturan untuk dapat memenuhi harapan masyarakat dalam memastikan terselenggaranya pemilu yang bebas dan adil.

5) Transparansi

Keseluruhan kredibilitas dari proses pemilihan umum secara substansial tergantung pada semua yang berkepentingan, baik KPU, Panwaslu, Partai Politik, pemerintah maupun masyarakat untuk ikut terlibat dalam formasi dan fungsi dari struktur dan proses pemilu. Dalam hal ini, komunikasi dan kerjasama semua stakeholder: KPU, panwaslu, partai politik dan institusiinstitusi dalam masyarakat harus dibangun atas dasar collective action untuk kepentingan bersama. 
Apa pun, pelaksanaan Pilkada langsung di seluruh Indonesia mesti berjalan sukses dalam arti demokratis, aman, dan damai. Dalam hal ini, kesuksesan Pilkada langsung tidak hanya dilihat dari perspektif kemajuan pelaksanaan otonomi daerah, khususnya yang tertuang dalam Undang Undang Nomor 18 Tahun 2014 tentang Pemerintahan Daerah, tetapi juga bagian inheren agenda reformasi politik, sebagaimana menjadi tuntutan mahasiswa saat meruntuhkan rezim Orde Baru.

\section{SIMPULAN}

Terjadinya konflik dan penyebabnya antara lain adanya ketidakpuasan dari pasangan calon atau pendukung pasangan calon ketika gugur dalam tahap pencalonan, Adanya rasa tidak puas pasangan calon terhadap hasil penghitungan Pilkada, Tahapan pendaftaran pemilih yang amburadul inilah yang mengakibatkan konflik pada pemungutan dan penghitungan suara, tidak bersedianya DPRD menetapkan hasil Pilkada. Cara mengatasi konflik antara lain conflict governance, kesadaran, demokrasi, mengkonstruksikan undang-undang, melaksanakan good government dan mempertimbangkan faktor penguatan masyarakat sipil dan modal sosial berupa kepercayaan antara warga dan elemen-elemen masyarakat.

\section{DAFTAR PUSTAKA}

\section{Buku}

Arbas, Cakra, 2012, Jalan Terjal Calon Independen pada Pemilukada di Provinsi Aceh, PT. Sofmedia, Jakarta.

Asshiddiqie, Jimly, 2008, Pokok-Pokok Hukum Tata Negara Indonesia Pasca Reformasi, BIP, Jakarta. 2010, Konstitusi dan Konstitusionalisme Indonesia, Sinar Grafika, Jakarta.

Bachrul, Elmi, 2002, Keuangan Pemerintah Daerah Otonom di Indonesia, 
Universitas Indonesia Press, Jakarta.

Bratakusumah, Deddy Supriady dan Dadang Solihin, 2002, Otonomi

Penyelenggaraan Pemerintahan Daerah, PT Gramedia Pustaka

Utama, Jakarta.

Budiardjo, Miriam, 2003, Dasar-Dasar Ilmu Politik, Gramedia Pustaka

Utama, Jakarta.

Gadjong, Agussalim Andi, 2007, Pemda (Kajian Politik Dan Hukum), PT.

Ghalia Indonesia, Jakarta.

Gaffar, Janedri M., 2012, Politik Hukum Pemilu, Kontpress, Jakarta.

Hadjon, Philipus., dkk, 2005, Pengantar Hukum Adminsitrasi Indonesia

(Introduction to the Indonesian Adminstrative Law), Gajah Mada

University Press, Yogyakarta.

Huda, Ni'matul, 2011, Hukum Tata Negara Indonesia, PT. RajaGrafindo

Persada, Jakarta.

Ikhsan, Edy dan Mahmul Siregar, 2009, Metode Penelitian dan Penulisan

Hukum Sebagai Bahan Ajar, Fakultas Hukum Universitas

Sumatera Utara, Medan.

Juanda, 2004, Hukum Pemerintahan Daerah Pasang Surut Hubungan

Kewenangan antara DPRD dan Kepala Daerah, Alumni, Bandung.

Juliardi, Budi, 2015, Pendidikan Kewarganegaraan Untuk Perguruan Tinggi,

PT. Rajawali Pers, Jakarta.

Kaloh, J., 2003, Kepala Daerah-Pola Kegiatan, Kekuasan, dan Perilaku Kepala

Daerah, dalam Pelaksanaan Otonomi Daerah, Gramedia, Jakarta 